\title{
Strategy to Become a Great Principal
}

\author{
Hottua Samosir ${ }^{1, *}$ Benyamin Situmorang $^{2}$, Eka Daryanto ${ }^{3}$
}

\author{
${ }^{1}$ Universitas Prima Indonesia Medan North Sumatra Indonesia \\ ${ }^{2,3}$ Postgraduate School Universitas Negeri Medan North Sumatra, Indonesia \\ *Corresponding author. Email: hottuarealy@gmail.com
}

\begin{abstract}
The purpose of education in a school is largely based on the expertise of a principal in leading, through good leadership all the potential possessed by the school will move and develop according to the needs and developments of the times. The purpose of this study was to determine the principal's strategy to become great. The principal is the main key and is one of the most important strategic factors in developing quality schools. The research conducted by using the literature study method. The results showed same strategies that implemented to become a great principal are: 1). Obey the rules. 2). Proficiency in using technology, 3) Spending time. 3). Quick date and caring. 5). Academic Assistance Skills. 6). Innovative Behaviour. 7) Pedagogical Leadership.
\end{abstract}

Keywords: great principal, leadership, technology.

\section{INTRODUCTION}

The existence of the principal in a school is like a captain on a ship, he becomes the determinant and determines where the ship goes and docks. Likewise the principal, he is the controller and determinant of where the school he leads is moving and what the target is.

The role of the principal is indeed so central that this role is the main key and is one of the most important strategic factors in developing quality schools [1]. Moreover, [2] stated that the success of achieving educational goals in a school, largely based on the expertise of a principal in leading; with good leadership all, the potential possessed by the school will move and develop according to the needs and developments of the times. The principal is a teacher who is appointed to the highest position or principal at school [3].

The principal in carrying out his duties must act professionally, namely in accordance with the main duties and functions as mandated by the applicable law. Professional heads try to make good use of being a leader. Next, [4] said that leadership involves a process of social influence, in this case the influence exerted by a person on others to structure activities and relationships within a group or organization.

Becoming a professional principal is the ideal endeavour of a principal's journey. Becoming a professional school principal is also a necessity, because so many studies prove that leadership affects various aspects of the world of education, such as [5] who proves the influence of school leadership and teacher performance on school effectiveness of Vocational Schools at Medan, and [6] proves the influence of principal's leadership and work motivation on the performance of state SMP Medan City, and [7] proves the influence of principal's leadership, work motivation, and organizational culture on the competence of high school teachers.

Great hopes are hung on a school principal, with the hope that through professional work he can bring the school he leads to a better direction than before, and bring benefit and welfare to all school members.

\section{METHOD}

This research method is the Library Research method, namely library research, as [8] argues that library research is a data collection technique by conducting a review study of related books, literatures, notes, and reports, with the problem solved. In this case, the author deepens, examines, and examines the literature related to the principal, then the author conducts an in-depth analysis, and then the author arranges it in the form of scientific articles. 


\section{RESULT AND DISCUSSION}

\subsection{Definition of School Principal}

The principal according to [9] is the person (teacher) who leads a school, or also known as the head teacher. Meanwhile [10] says that the principal is a functional teacher who is given the task to lead a school where the teaching and learning process is held or a place where there is interaction between teachers who give lessons and students who receive lessons. And [11], [12] said that the principal can be defined as a school leader or an institution where he receives and gives lessons, a teacher who is appointed to the highest structural position or principal in the school.

Meanwhile, the definition of a principal according to the Minister of National Education Regulation No. 28 of 2010 is a teacher who is given additional duties to lead Kindergartens/Raudhotul Athfal, Extraordinary Kindergartens, Schools/Madrasah Ibtidaiyah, Extraordinary Elementary School, Junior High School/ Madrasah Tsanawiyah, Extraordinary Junior High School, Senior High School/ Madrasah Aliyah, Vocational High School/ Vocational Aliyah Madrasah, Extraordinary High Schools which are not International Standard Schools or which have not been developed into International Standard Schools.

Based on some of these definitions, can be concluded that the notion of a principal is a teacher who is formally appointed and assigned to be a leader for a school to empower and lead school resources in order to improve school quality.

\subsection{Qualification of School Principal}

The qualifications of a school principal according to the Regulation of the Minister of National Education of the Republic of Indonesia No. 13 of 2007 concerning School Principal Standards, including:

\subsubsection{General Qualification.}

General qualification are: a) having academic qualifications of diploma four (D-IV) or bachelor (S1) non-education or education at an accredited tertiary institution. b) The maximum age limit when appointed as school leader is 56 years. c) According to each school level, at least have teaching experience for 5 (five) years except in Kindergarten/Raudhatul Athfal, at least have teaching experience for 3 (three) years in Kindergarten, and d) Those who are non-PNS must be equal to the rank and at least have the rank of III/c for civil servants issued by the foundation or authorized institution..

\subsubsection{Specific Qualification.}

The specific qualification of school principal are: a) Status as a teacher, b) have an educator charter as a teacher, and c. Have a school leader charter set and issued by government agencies. While the competencies that must be possessed by school leaders include social, managerial, personality, supervision, and entrepreneurial competencies.

\subsection{Duties and Functions}

The principal duties of school principals described in Education Minister of Indonesia Republic Number 6 of 2018 chapter 6 article 15 as follows: (1) the principal's workload is entirely to carry out the main managerial tasks, entrepreneurship development, and supervision of teachers and education staff. (2) The principal's workload as referred to in paragraph (1) aims to develop schools and improve school quality based on 8 (eight) national education standards. (3) In the event of a shortage of teachers in the education unit, the Principal may carry out the task of learning or mentoring so that the learning or mentoring process continues in the education unit concerned. (4) The principal who carries out the task of learning or mentoring as referred to in paragraph (3), the task of learning or mentoring is an additional task outside the main task. (5) The workload for school principals who placed in Indonesian Overseas Schools in addition to carrying out the workload as referred to in paragraph (1) and paragraph (3) carries out the promotion of Indonesian culture [13]

There are various duties and responsibilities of the principal in managing the school. Educational leaders are also obliged to provide guidance that means trying to make the management, assessment, guidance, supervision, and development of education carried out better [14]. Next, [14] stated that the function of the principal seen from several points of view. Together with educational institutions, the principal functions are as follows: as a manager, as a leader, and as an educator [15].

\subsection{Authorities}

Based on the opinion of [15], the principal's authority includes 7 areas, namely: 1). Academic fields that have a relationship in the teaching and learning process both outside and inside the school or madrasa. 2). School finance and administration. 3). Student field. 4). School supplies and school buildings. 5). Personnel field. 6). Field of learning equipment. 7). Community and school. In the Government Regulation of the Republic of Indonesia Number 28 of 1990 chapter VI article 12 paragraph 1 it is explained that the Principal is responsible for the implementation of educational activities, school administration, coaching other educational staff and the utilization and maintenance of facilities and infrastructure.

\subsection{Legal Basis of School Principal}

Some of many legal bases for the existence of school principals in Indonesia include: 1) Law of the Republic of Indonesia Number 20 of 2003 concerning the National Education System. 2) Law of the Republic of Indonesia 
Number 14 of 2005 concerning Teachers and Lecturers. 3) Regulation of the Minister of National Education Number 13 of 2007 concerning Standards for Principals/Madrasahs. 4. Regulation of the Minister of National Education Number 28 of 2010 concerning Assignment of Teachers as Principals of Schools/Madrasahs. 5) Regulation of the Minister of Education and Culture Number 6 of 2018 concerning Assignment of Teachers as Principals.

\subsection{Responsibilities}

From several articles found as many as 18 (eighteen) obligations of a school principal, [16] summarizes these obligations including: 1) Elaborating the vision into the mission of quality objectives. 2) Develop targets and achieved goals. 3) Assessing the opportunities, challenges, weaknesses and strengths of the school. 4) Establish annual work plans and strategic work plans. 5) Responsible for making school funding decisions. 6) Involve school committees and teachers when making important decisions. 7) Creating an intense relationship with parents and the community. 8) Improve and maintain the work motivation of educators and education staff based on the code of ethics and regulations. 9) Creating an effective learning environment. 10) Responsible for planning the implementation of the school curriculum. 11) Organizing and compiling a supervision program. 12) Improving the quality of education. 13) Maintain the goodwill of the profession, position and institution. 14) Disseminate information to all school members properly. 15) Fostering, maintaining and assisting the school environment and supporting conducive teaching and learning activities and fostering the professionalism of educators 16) School management and the utilization of healthy, effective, efficient and safe resources must be accounted for. 17) Forming cooperation between parents, community and committees, and 18) Delegating some of the authority and duties in accordance with their respective fields to the deputy principal.

\subsection{Principles}

Based on the opinion of [17], the principles that must do by the principal consist of: 1) Orientation to achieving goals. 2) Implement participatory leadership by developing the role of educators in making decisions. 3) Must be a leader who can issue new ideas through increasing confidence in himself to expand actions that can encourage change. 4) Can provide confidence so that the perception of educators arises that the principal supports work activities. 5) Expanding collaboration between educators either through formal or informal interactions.

\subsection{Ethics Code}

The professional code of ethics is an ethical structure formed from an agreement by a community group. In the code of ethics, there are social norms and legal norms.

Author [18] states that the attitudes and behaviours or code of ethics that school principals need to have are as follows. 1) Has responsibility for the position entrusted to him. 2) Have a high concern and commitment to achieve something meaningful during his tenure. 3) Enforce time discipline with full awareness that discipline is the key to success. 4) Carry out every task and activity with full responsibility, and always clear the value of each activity in relation to improving the quality of graduates. 5) Proactive. 6) Having the will and courage to solve every problem faced by the school. 7) Become a communicative leader and a motivator for his nature more accomplished, and not be bossy. 8) Have sensitivity and sense of belonging. 9) Dare to correct every mistake firmly and act wisely, and optimistically.

\subsection{Competencies}

In the Regulation of the Minister of National Education Number 13 of 2007 concerning Standards for Principals/Madrasahs, explained that a school principal must have the following competencies: Personality Competence; Managerial Competence; Entrepreneurship Competence; Supervision Competence; and Social Competence.

Sharpen the opinion above, [19] explained that the competence of the principal seen in the following matters: 1). Shows the willingness and ability to do a job; 2). Having the ability, skill, knowledge, authority and proficiency in working shows the nature of competent people; 3). Shows performance rationally to achieve goals and can provide satisfaction based on conditions.

\subsection{Strategies to become a great principal}

Some things to make a great school principal according to [20] are to understand or comprehensively understand their managerial abilities and performance in the context of leading a school so that the school can have a cultural nuance that is in accordance with community development. Furthermore, [20] states that a great principal must have;

a. knowledge and insight that is far ahead, knows what actions to take and understands how to do it;

b. the ability to align and coordinate resources to achieve and meet school goals and needs;

c. expertise in making decisions accurately, quickly, precisely and swiftly;

d. expertise in mobilizing resources so that they can reach and inspire their subordinates in implementing or achieving school goals;

e. Tolerant for differences in each person. 
In addition, [16], an Indonesian education practitioner, conveys 13 critical factors related to the success of school principals in developing student achievement, namely; 1). Creating a mission that is focused on efforts to improve student achievement; 2). High expectations for all students in studying the subject matter; 3). Appreciate and encourage the implementation of good learning practices; 4). Understand how to lead a school organization; 5). Utilize data to initiate efforts to improve student achievement and educational practice; 6). Keeping everyone focused on student achievement; 7). Make parents as partners and build collaboration for the benefit of student education; 8). Understand the change process and manage it; 9). Understanding how adults learn; 10). Utilize and manage time in innovative ways; 11). Obtain and use various resources wisely; 12). Seek and obtain support from various parties; 13). Continuous learning and cooperating with peers.

Meanwhile, [21] explains that there are 7 things that can be done to become an inspirational school principal, namely: 1). Noble character; 2). Intelligent; 3). Have foresight; 4). Have a creative soul; 5). Firm and disciplined; 6). Humanist; 7). Have integrity.

Based on the explanations of the various experts, the authors can say that the strategies for becoming a professional school principal are:

a. Obey the rules. That is, doing and working is always guided by the rules that have been set by the state, local government, and the schools own rules.

b. Take the time. Namely being a person who can provide a lot of time for his school, interact, collaborate, and collaborate with teachers, students and other school members to do positive things for the betterment of his school;

c. Caring and responsive. That is, it can help the teacher's work in interpreting the big ideas of the vision and mission statements in the practice of implementing daily teaching and learning activities. Teachers can do creative things, but not because they are creative people, but because there are principals who are willing to step up if there is a problem or if they make a mistake. The principal is also caring and quick to the students, immediately the problems faced by the students are quickly responded to in a positive manner. Likewise for other school members, the principal shows concern and is quick to respond to the various problems they face;

d. Utilization of Information Technology (IT). Seeking an easy internet presence in the school, which can be used for various school interests [22]; e. Academic Assistance. Creating academic pathways to support students to succeed based on their unique interests, skills and talents. Both linking vocational and professional initiatives and partnerships, internships, as well as those that will help develop schools into innovative, creative and competitive schools;

f. Innovative. Plant and grow innovation successfully and anticipate problems that may arise suddenly in the process of transforming change for the better.

g. Pedagogical leadership. The ability to form character, so that subordinates have positive traits. The pedagogical principal is gradually able to build the character of teachers and students to positive behaviours. With pedagogical leadership, it will form the personality of teachers and students who are characterized by honest, goodhearted behaviours, accustomed to the truth and competent in their fields.

\section{CONCLUSION}

Based on the description above, it can be concluded that how to become a great principal concluded that a school principal should fulfil the following matters: 1). Obey the rules. 2). Taking the time. 3). Caring and responsive. 4). IT Utilization. 5). Academic Assistance. 6). Innovative, and 7) Pedagogical leadership.

\section{REFERENCES}

[1] Amriani, A., Siburian, P., Wau, Y., \& Sihotang, D. O. (2020). Best Leadership Principals of Remote Elementary Schools in the Future. 488(Aisteel), 247-251.

https://doi.org/10.2991/assehr.k.201124.052

[2] Muspawi, Mohamad, et.all. (2020). Upaya Kepala Sekolah Untuk Peningkatan Kompetensi Profesional Guru. Jurnal Ilmiah Universitas Batanghari Jambi, 20 (1)

[3] Lee-Piggott, R. (2019), "New Principals' Emotions: Interactions with 'Inherited' School Cultures", Oplatka, I. and Arar, K. (Ed.) Emotion Management and Feelings in Teaching and Educational Leadership (Studies in Educational Administration), Emerald Publishing Limited, Bingley, pp. 173-191. https://doi.org/10.1108/978-1-78756-010920191012

[4] Yuliani Dkk. (2016). Peran Kepemimpinan Kepala Sekolah Dalam Membina Kompetensi Sosial (Pelayanan Prima) Tenaga Administrasi Sekolah. Jurnal Manajemen, Kepemimpinan, dan Supervisi Pendidikan. Volume 1, No. 2 
[5] Siburian, Paningkat. (2012). Pengaruh Budaya Organisasi, Perilaku Inovatif, Kepuasan Kerja, dan Motivasi Kerja Kepala SMK (Pengembangan model teoretis Kinerja melalui Studi Empiris pada SMK di Kota Medan). Disertasi Medan: Program Pascasarjana Universitas Negeri Medan

[6] Sinaga et al., (2020). The Influence of Organizational Culture, Leadership, Cognitive Ability, and Work Motivation on Employees Performance. 384(Aisteel), 620-624. https://doi.org/10.2991/aisteel-19.2019.141

[7] Syakir Dkk., (2015). Pengaruh Kepemimpinan Kepala Sekolah, Motivasi Kerja, dan Budaya Organisasi Terhadap Kompetensi Guru SMA. Jurnal Akuntabilitas Manajemen Pendidikan. Volume 3, No 2, September 2015: 226-240

[8] Sri Rahayu, R. (2018). Studi Literatur: Peranan Bahasa Inggris Untuk Tujuan Bisnis Dan Pemasaran. 1(4), 149.

[9] KBBI, (2021). Kamus Besar Bahasa Indonesia (KBBI). [Online] Available at: http://kbbi.web.id/pusat, [Diakses 21 Juni 2021].

[10] Rajagukguk, J., Sihotang, D. O., Situmorang, B., \& Rahman, A. (2020). A superior Leadership style in Schools (Case study at SMA Negeri 1 Medan) . 488(Aisteel), 277-280. https://doi.org/10.2991/assehr.k.201124.058

[11] Asmani, Jamal Ma'mur. (2012). Tips Menjadi Kepala Sekolah Profesional. Jogjakarta: DIVA Press

[12] Siahaan, T. M., Sihotang, D. O., Lumbanbatu, J. S., \& Purba, S. (2020). Principals School Commitment in the Implementation, and Supervision Quality of Education in the Future. 488(Aisteel), 298-301. https://doi.org/10.2991/assehr.k.201124.062

[13] Wahjosumidjo. (2005). Kepemimpinan Kepala Sekolah. Jakarta. Raja Grafindo Persada

[14] Windari et al., (2020). Become a Professional Teacher in the Future. 488(Aisteel), 214-218. https://doi.org/10.2991/assehr.k.201124.046

[15] Maghfiroh, A. (2010). Peran Kepala Sekolah Sebagai Supervisor dalam Peningkatan Mutu Guru PAI di SMP Nasima Semarang. Disertasi. IAIN Walisongo

[16] Nurmadiah. (2017). Profesionalisme Kepemimpinan Kepala Sekolah (kajian konsep dan teoritis). Jurnal keislaman \& peradaban volume 5 (1).

[17] Fullan, Michael, 2001. Leading in A Culture of Change, Jossey-Bass, San Francisco
[18] Mulyasa, E. (2011). Menjadi Kepala Sekolah Profesional. Bandung: Remaja Rosdakarya

[19] Purba, Sukarman. (2009). Peningkatan Kompetensi melalui Pementoran dalam Mewujudkan Profesionalisme Kepala Sekolah. Jurnal Unimed. volume 2 (2).

[20] Zulkifli, Z. (2014). Strategi Kepala Sekolah Dalam Meningkatkan Kompetensi Profesional Guru Pada SMA Negeri 1 Peukan Bada Kabupaten Aceh Besar. Jurnal Ilmiah Didaktika: Media Ilmiah Pendidikan dan Pengajaran, 14 (2)

[21] Iftach, G. and Shapira-Lishchinsky, O. (2019), "Principals' perceptions of school identity: logo, vision and practice", International Journal of Educational Management, Vol. 33 No. 6, pp. 11701184. https://doi.org/10.1108/IJEM-11-2018-0365

[22] Sihotang, D. O. (2019). Optimalisasi Penggunaan Google Class Room Dalam Peningkatan Minat Belajar Bahasa Inggris Siswa Di Era Revolusi Industri 4.0 (Studi Kasus di SMK Swasta Arina Sidikalang). Jurnal Teknologi Kesehatan Dan Ilmu Sosial (Tekesnos), 1(1), 77-81. http://e-journal.sarimutiara.ac.id/index.php/tekesnos/article/view/981 